\title{
PENGEMBANGAN INFRASTUKTUR TERMINAL PENUMPANG PADA PELABUHAN BANDAR BINTAN TELANI (BBT) DALAM MENDUKUNG PARIWISATA PULAU BINTAN
}

\author{
Triani Octavia ${ }^{1, *)}$, Bambang Triatmodjo ${ }^{2}$, Sigit Priyanto ${ }^{3}$ \\ ${ }^{1, *}$ Departemen Teknik Sipil dan Lingkungan, Universitas Gadjah Mada, Yogyakarta \\ Email: triani.octavia@ugm.ac.id \\ ${ }^{2}$ Departemen Teknik Sipil dan Lingkungan, Universitas Gadjah Mada, Yogyakarta \\ Email: bambangtri@ugm.ac.id \\ ${ }^{3}$ Departemen Teknik Sipil dan Lingkungan, Universitas Gadjah Mada, Yogyakarta \\ Email: spriyanto2007@ugm.ac.id
}

\begin{abstract}
An evaluation of the condition and performance of the BBT Port needs to be carried out because of the significant increase in the number of tourist visits to the Bintan Beach International Resort area. Still, since its inauguration in 1994, the port has not changed much. Passenger terminal needs are commonly defined through projections using the exponential trend method based on ship and visitor flows in the last five years. A port performance is based on BOR (Berth Occupancy Ratio) calculation. In contrast, for the performance evaluation of passenger terminal services is based on the perception of tourists as passenger terminal users obtained from the questionnaire results with a Likert scale and the Importance Performance Analysis (IPA) method from the IPA, interviews with the BBT port manager, are conducted by using the Strength Weakness Opportunities Threats (SWOT) method to formulate the development strategy. The analysis result shows that it needs to increase the waiting area up to $613 \mathrm{~m}^{2}$ in 2033, and the parking area of $17,173 \mathrm{~m}^{2}$, while the BOR at the BBT port is still in a proper category, by $24.11 \%$ of the UNCTAD $50 \%$ requirement. In evaluating the passenger satisfaction to the port services, the improvement focuses on the priority quadrant, namely the physical condition of the BBT port facilities. Next, formulating a development strategy in terms of physical aspects and management to adjust the passenger needs, and the BBT port is ready to face business competition in the future.
\end{abstract}

Keywords: Tourism seaport, exponential trend, IPA, SWOT

\section{PENDAHULUAN}

Pulau Bintan merupakan pulau terbesar di dalam gugusan Kepulauan Riau yang termasuk dalam wilayah administrasi Kabupaten Bintan. Pulau Bintan memiliki potensi yang cukup kaya, baik dari sektor pertambangan, industri, terutama pada sektor pariwisata. Ditambah dengan posisi Pulau Bintan yang cukup strategis karena berbatasan dengan negara tetangga yakni Singapura dan Malaysia menjadikan perkembangan Pulau Bintan melaju cukup pesat. Salah satu kawasan wisata yang menjadi andalan Pulau Bintan adalah Bintan Beach International Resort (BBIR) yang berada di Kecamatan Teluk Sebong, Kabupaten Bintan.
Beberapa Tahun terakhir peningkatan jumlah kunjungan wisatawan ke kawasan Bintan Beach Internatinal Resort cukup signifikan, hal ini dipicu oleh trend travelling yang sedang marak saat ini serta kegiatan olahraga bertaraf internasional yang digelar setiap tahunnya. Pelabuhan BBT (Bandar Bintan Telani), sebagaimana ditunjukkan Gambar 1, yang dikelola oleh PT. BRC merupakan pintu gerbang masuknya para wisatawan asing tersebut ke kawasan BBIR, namun sejak diresmikan pada tahun 1994 pelabuhan ini belum banyak mengalami perubahan. 


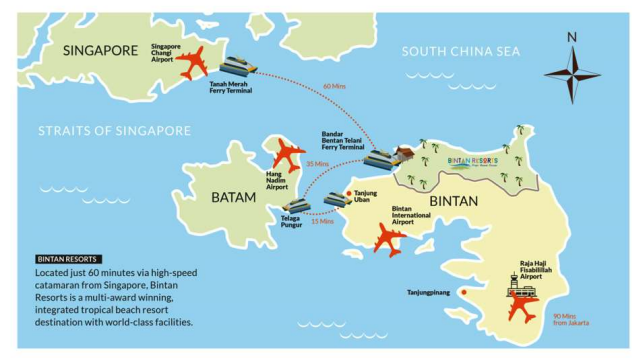

Gambar 1. Peta lokasi Pelabuhan BBT (Sumber : PT.BRC)

Oleh karena itu Pelabuhan BBT perlu dievaluasi serta dikembangkan agar dapat mengimbangi jumlah wisatawan untuk mengatasi kepadatan terminal penumpang pada masa depan yang juga akan mempengaruhi tingkat pelayanan dan kepuasan wisatawan selaku pengguna jasa di atas, maka dirumuskan permasalahan sebagai berikut:

1. apakah Kondisi Pelabuhan BBT pada saat ini masih cukup menampung arus penumpang dan arus kapal pada masa yang akan mendatang?,

2. bagaimana kinerja operasional pelabuhan pada saat ini?,

3. bagaimana perumusan strategi dalam pengembangan Pelabuhan BBT yang dapat menunjang perannya sebagai pelabuhan pariwisata?

Sedangkan tujuan dari penelitian ini adalah untuk melakukan evaluasi ketersediaan fasilitas pelabuhan saat ini, melakukan perhitungan kebutuhan fasilitas Pelabuhan BBT di masa yang akan datang, melakukan evaluasi kinerja pelayanan operasional pelabuhan, serta merumuskan strategi pengembangan Pelabuhan BBT.

\section{METODE PENELITIAN}

\section{Proyeksi jumlah pertumbuhan}

Untuk menentukan kebutuhan terminal penumpang dimasa yang akan datang, maka diperlukan proyeksi untuk meramalkan jumlah arus kapal dan pengunjung, yakni dengan trend method, membandingkan 2 metode yakni regresi linear dan eksponensial untuk melihat metode mana yang paling tepat untuk meramalkan jumlah wisatawan dimasa depan. Setelah dilakukan perhitungan, kemudian metode yang dipilih adalah metode eksponensial sebagaimana ditunjukkan persamaan (1),

$\log Y=\log a+X \log (1+b)$

karena memiliki nilai $\mathrm{R}^{2}$ terbesar dan nilai deviasi terkecil.

\section{Menghitung kebutuhan fasilitas pelabuhan}

1. Dermaga

Penentuan panjang dermaga menurut (IMO) International Maritim Organization adalah sebagaimana ditunjukkan persamaan (2).

$L \rho=n L o \alpha+(n+1) \times 10 \% \times \operatorname{Lo\alpha }$

dengan,

$L \rho \quad$ : panjang dermaga,

Lo $\alpha$ : panjang kapal yang ditambat,

$n \quad$ : jumlah kapal yang di tambat.

2. Terminal Penumpang

Berdasarkan Lampiran II KM 52 Tahun 2004 penetapan kebutuhan lahan daratan dan perairan dalam rencana induk pelabuhan dapat ditentukan dengan persamaan (3) berikut.

$\mathrm{A}=\mathrm{A}_{1}+\mathrm{A}_{2}+\mathrm{A}_{3}+\mathrm{A}_{4}+\mathrm{A}_{5}$

dengan,

A =luas total area gedung $\left(\mathrm{m}^{2}\right)$,

$A_{1}=$ luas ruang tunggu $\left(\mathrm{m}^{2}\right)$,

$\mathrm{A}_{2}=$ luas ruang kantor pengelola,

$\mathrm{A}_{3}=$ luas ruang kantin/cafetaria,

$\mathrm{A}_{4}=$ luas ruang utilitas,

$\mathrm{A}_{5}=$ luas ruang ruang publik.

Nilai $A_{1}$ pada persamaan (3) dapat dihitung dengan persamaan (4) berikut.

$\mathrm{A}_{1}=\mathrm{A}^{\prime} \mathrm{n} \mathrm{N} \mathrm{x} \mathrm{y}$

dengan,

$\mathrm{A}^{\prime}=$ luas area untuk setiap penumpang (1,2 $\mathrm{m}^{2} /$ orang),

$\mathrm{N}=$ jumlah kapal yang merapat pada saat yang bersamaan,

$\mathrm{y}=$ rasio fluktuasi $(1,2)$, 


$$
\begin{aligned}
\mathrm{n}= & \text { jumlah penumpang dalam satu } \\
& \text { kapal, } \\
\mathrm{x}= & \text { rasio konsentrasi atau jumlah } \\
& \text { penumpang terbanyak/jam } \\
& \text { tersibuk dengan penumpang per } \\
& \text { kapal }(1,0-1,6), \\
\mathrm{A}_{2}= & \left(15 \% \mathrm{~A}_{1}\right), \\
\mathrm{A}_{3}= & \left(15 \% \mathrm{~A}_{1}\right), \\
\mathrm{A}_{4}= & \left(25 \%\left(\mathrm{~A}_{1}+\mathrm{A}_{2}+\mathrm{A}_{3}\right)\right), \\
\mathrm{A}_{5}= & \left(10 \%\left(\mathrm{~A}_{1}+\mathrm{A}_{2}+\mathrm{A}_{3}+\mathrm{A}_{4}\right)\right) .
\end{aligned}
$$

3. Areal Parkir

Kebutuhan luas parkir dapat ditentukan dengan persamaan (5) dan nilai $\mathrm{B}_{1}$ serta $\mathrm{B}_{2}$ dapat dihitung dengan persamaan (6) dan persamaan (7).

$$
\begin{aligned}
\mathrm{B}= & \mathrm{B}_{1}+\mathrm{B}_{2} \\
\mathrm{~B}_{1}= & \mathrm{a}_{1} \mathrm{Nxy} \\
\mathrm{B}_{2}= & \mathrm{a}_{1} \mathrm{~N} \mathrm{xyz} \frac{1}{n 2} \\
\text { dengan, } & \\
\mathrm{B}_{1}= & \text { luas parkir kendaraan menginap, } \\
\mathrm{B}_{2}= & \text { luas parkir kendaraan penjemput } \\
& \text { dan pengantar, } \\
\mathrm{a}= & \text { luas areal yang dibutuhkan untuk } \\
& \text { satu unit kendaraan, } \\
\mathrm{n}_{1}= & \text { jumlah penumpang dalam satu } \\
& \text { kapal, } \\
\mathrm{n}_{2}= & \text { jumlah penumpang dalam satu } \\
& \text { kendaraan (rata-rata } 8 \text { orang/unit), } \\
\mathrm{N}= & \text { jumlah kapal datang/berangkat } \\
& \text { pada saat yang bersamaan, } \\
\mathrm{x}= & \text { rata-rata pemanfaatan }(1,0), \\
\mathrm{y}= & \text { rasio konsentrasi (1,0-1,6), } \\
\mathrm{z}= & \text { rata-rata pemanfaatan }(1: \text { seluruh } \\
& \text { penumpang meninggalkan } \\
& \text { terminal dengan kendaraan). }
\end{aligned}
$$

\section{Menghitung Berth Occupancy Ratio}

Berth Occupancy Ratio (BOR) atau tingkat penggunaan dermaga, merupakan perbandingan antara waktu penggunaan dermaga dengan waktu yang tersedia dalam periode waktu tertentu yang dinyatakan dalam prosentase. Nilai $B O R$ dihitung menggunakan persamaan (8) yang tergantung pada jumlah dan jenis tambatan (Triatmodjo, 2009).

BOR $=\frac{\text { Vs } \times \text { St }}{\text { WaktuEfektif } \times n} \times 100 \%$

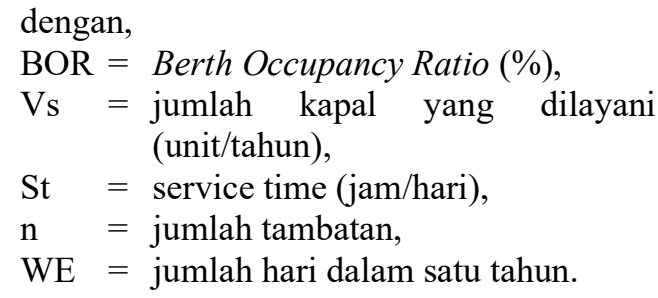

\section{Penentuan Sampel}

Penentuan besarnya sampel dari populasi digunakan teknik simple random sampling sebagaimana persamaan (9),

$n=\frac{N}{1+N(e)^{2}}$

digunakan jumlah responden sebanyak 100 orang

\section{Uji Validitas dan Reliabilitas}

Pengujian validitas instrumen dimaksudkan untuk mendapatkan alat ukur yang shahih dan terpercaya. Menurut Arikunto (2013) adapun penghitungan nilai validitas dapat dilakukan dengan persamaan (10).

$r_{x y}=\frac{n(\Sigma x y)-(\Sigma x)(\Sigma y)}{\sqrt{\left(n\left(\Sigma x^{2}\right)-(\Sigma x)^{2}\right)\left(n\left(\Sigma y^{2}\right)-(\Sigma y)^{2}\right)}}$

dengan,

$r_{x y}=$ koefisien korelasi produk momen Pearson,

$\mathrm{n}=$ jumlah pengamatan,

$\mathrm{x}=$ jumlah pengamatan variabel $\mathrm{x}$,

$\mathrm{y} \quad=$ jumlah pengamatan variabel $\mathrm{y}$.

Dengan ketentuan nilai validitas, apabila nilai $r_{x y}>$ rtabel maka alat ukur tersebut dapat dinyatakan valid, begitu pula sebaliknya. Sedangkan uji reliabilitas digunakan untuk mengetahui tingkat kepercayaan terhadap alat pengumpul data sebagaimana ditunjukkan dalam persamaan (11)

$$
\mathrm{r}_{\mathrm{i}}=\left(\frac{\mathrm{n}}{\mathrm{n}-1}\right)\left(1-\frac{\sum \mathrm{s}_{\mathrm{i}}^{2}}{\sum \mathrm{s}_{\mathrm{t}}^{2}}\right)
$$

dengan,

$r_{i}=$ reliabilitas instrumen,

$\mathrm{n}=$ jumlah butir pertanyaan,

$\mathrm{Si}^{2}=$ varians butir,

$\mathrm{St}^{2}=$ varians total.

Dengan ketentuan nilai reliabilitas adalah 
apabila nilai $r_{i}>r_{\text {tabel, }}$ maka alat ukur tersebut dapat dinyatakan reliabel dan sebaliknya.

\section{Service Quality}

Menurut Tjiptono, et al (2007) lima dimensi dalam pengukuran kualitas pelayanan adalah sebagai berikut,

1. berwujud (tangible),

2. reliabilitas (reliability),

3. ketanggapan (responsiveness),

4. jaminan (assurance),

5. empati (emphaty).

IPA (Importance - Performance Analysis)

IPA merupakan teknik analisis yang digunakan untuk mengidentifikasi faktorfaktor kinerja penting apa yang harus ditunjukkan oleh suatu perusahaan dalam memenuhi kepuasan para pengguna jasa mereka (Martila dan James, 1977). Dalam penelitian ini variabel $\mathrm{x}$ menunjukkan tingkat kepuasan terhadap kepuasan pelanggan sedangkan variabel y menunjukkan tingkat kepentingan sebagaimana ditunjukkan dalam persamaan (12).

$T k i=\frac{x i}{y i} \times 100$

dengan,

$T k i=$ tingkat kesesuaian responden,

$x i=$ skor penilaian kinerja perusahaan,

$y i=$ skor penilaian kepentingan pelanggan.

Selanjutnya, penghitungan rata-rata penilaian tingkat kepentingan (importance) dan kinerja (performance) untuk setiap item atribut dapat dilakukan dengan persamaan (13).

$$
\overline{X i}=\frac{\sum_{i=1}^{k} X i}{n} \quad \bar{Y} i=\frac{\sum_{i=1}^{k} Y i}{n}
$$

dengan,

$X i=$ skor rata-rata tingkat penilaian atribut kinerja,

$Y i=$ skor rata-rata tingkat penilaian atribut kepentingan ke-i,

$n=$ jumlah responden.
Nilai rata-rata tingkat kepuasan dan kepentingan atribut yang diperoleh dari responden akan menentukan letak garis yang akan membagi diagram kartesius menjadi empat kuadran seperti pada Gambar 2.

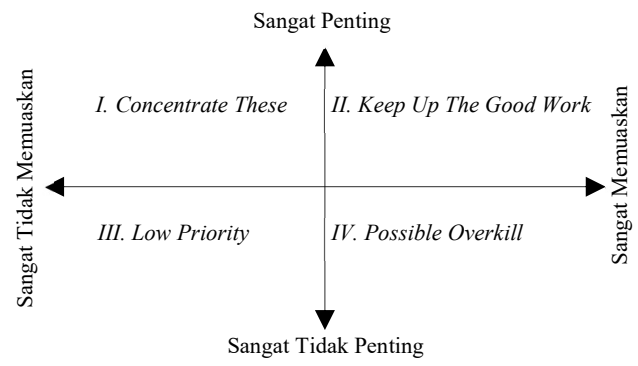

Gambar 2. Diagram kartesius

Sumber : Martila dan James (1977)

\section{Analisa SWOT (Strengths Weakness Op-} portunities Threats)

Analisis SWOT menurut Rangkuti (2004) merupakan identifikasi berbagai faktor secara sistematis untuk merumuskan strategi pengembangan pengusahaan sebagaimana ditunjukkan Tabel 1 berikut.

Tabel 1. Matriks analisa SWOT

\begin{tabular}{|c|c|c|}
\hline & $\begin{array}{l}\text { STRENGTHS } \\
\text { (S) }\end{array}$ & $\begin{array}{c}\text { WEAKNESSES } \\
(W)\end{array}$ \\
\hline & $\begin{array}{l}\text { Tentukan Faktor- } \\
\text { Faktor Kekuatan } \\
\text { Internal }\end{array}$ & $\begin{array}{c}\text { Tentukan } \\
\text { Faktor- Faktor } \\
\text { Kelemahan } \\
\text { Internal }\end{array}$ \\
\hline $\begin{array}{c}\text { OPPORTUNIES } \\
\text { (O) }\end{array}$ & $\begin{array}{l}\text { STRATEGI } \\
S-O(I)\end{array}$ & $\begin{array}{c}\text { STRATEGI } \\
W-O(I I)\end{array}$ \\
\hline $\begin{array}{c}\text { Tentukan } \\
\text { Faktor- Faktor } \\
\text { Peluang } \\
\text { Eksternal }\end{array}$ & $\begin{array}{c}\text { Ciptakan strategi } \\
\text { yang } \\
\text { menggunakan } \\
\text { kekuatan untuk } \\
\text { memanfaatkan } \\
\text { peluang }\end{array}$ & $\begin{array}{c}\text { Ciptakan strategi } \\
\text { yang } \\
\text { meminimalkan } \\
\text { kelemahan untuk } \\
\text { memanfaatkan } \\
\text { peluang }\end{array}$ \\
\hline $\begin{array}{l}\text { TREATHS } \\
\text { (T) }\end{array}$ & $\begin{array}{c}\text { STRATEGI } \\
S-T(I I I)\end{array}$ & $\begin{array}{c}\text { STRATEGI } \\
W-T(I V)\end{array}$ \\
\hline $\begin{array}{c}\text { Tentukan } \\
\text { Faktor- Faktor } \\
\text { Ancaman } \\
\text { Eksternal }\end{array}$ & $\begin{array}{l}\text { Ciptakan strategi } \\
\text { yang } \\
\text { menggunakan } \\
\text { kekuatan untuk } \\
\text { mengatasi } \\
\text { ancaman }\end{array}$ & $\begin{array}{c}\text { Ciptakan strategi } \\
\text { yang } \\
\text { meminimalkan } \\
\text { kelemahan dan } \\
\text { menghindari } \\
\text { ancaman }\end{array}$ \\
\hline
\end{tabular}

Sumber : Rangkuti (2004).

Sebelum menyusun perumusan strategi terlebih dulu mengidentifikasi faktor-faktor yang menjadi variable dan atribut, yakni dengan metode Faktor Strategi Eksternal 
(EFAS) dan Faktor Strategi Internal (IFAS). Adapun tahapan perhitungan $E F A S$ dan IFAS adalah,

1. menentukan faktor-faktor yang berpengaruh,

2. menentukan bobot pada setiap faktor dari 1 (tidak penting) sampai 5 (sangat penting),

3. menentukan rating setiap critical success factor antara 1 sampai 5 ,

4. mengalikan bobot nilai dengan nilai peringkat untuk mendapatkan skor untuk setiap variabel,

5. menjumlahkan semua skor untuk mendapatkan skor total terminal yang dinilai.

Bobot setiap variabel diperoleh dengan menentukan nilai setiap variabel terhadap jumlah nilai keseluruhan variabel sebagaimana persamaan (14) berikut.

$A_{i}=\frac{X_{i}}{\sum_{i=1}^{n} X_{i}}$

dengan,

$A_{i}=$ bobot variabel ke-i,

$n$ = jumlah variabel,

$i=1,2,3, \ldots, \mathrm{n}$,

$X_{i}=$ nilai variabel ke-i.

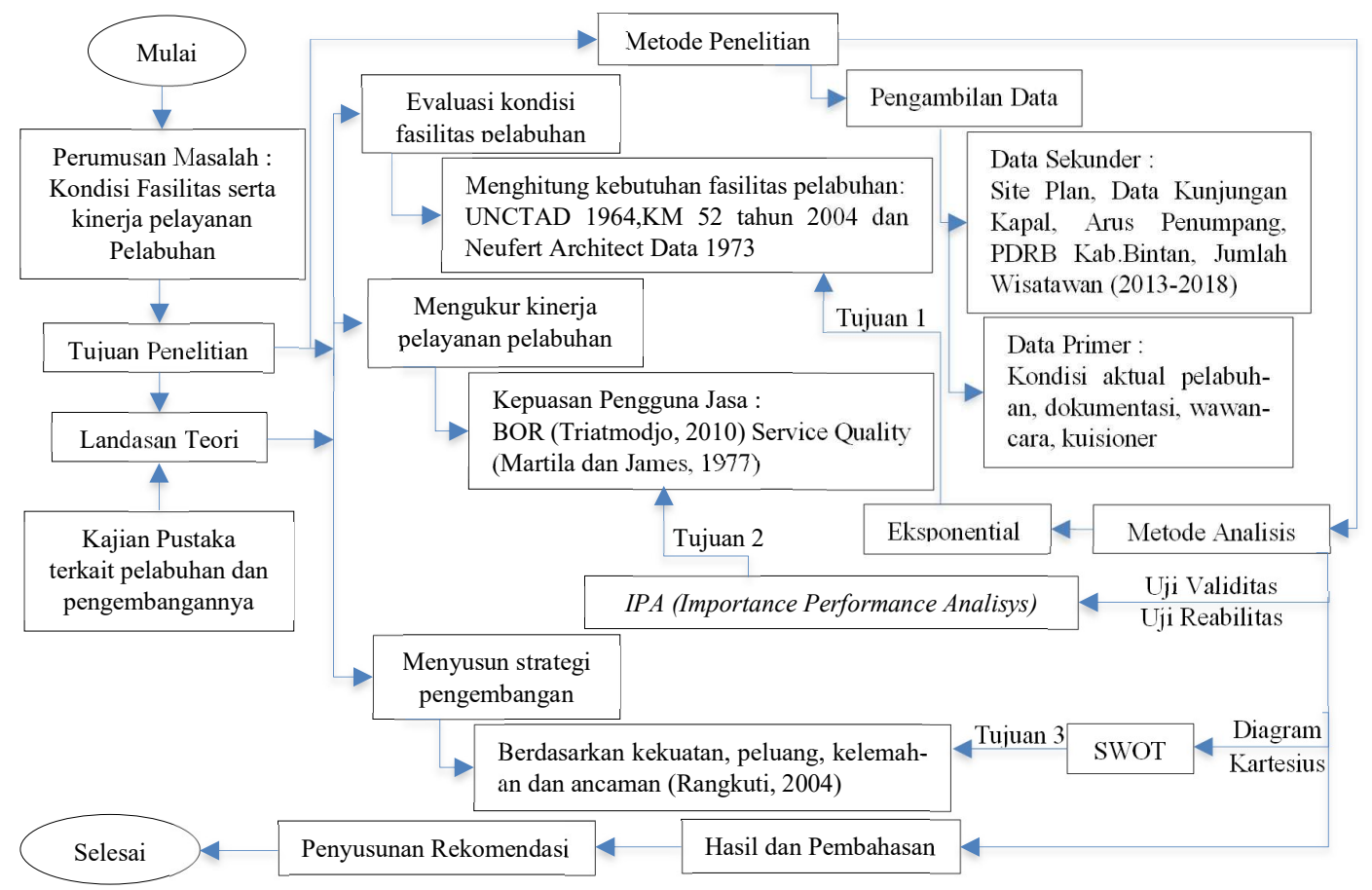

Gambar 3. Bagan alir penelitian Sumber: Analisa Peneliti (2019)

\section{HASIL DAN PEMBAHASAN}

\section{Proyeksi Kebutuhan Fasilitas Pelabuhan}

Proyeksi arus penumpang pada pelabuhan sampai dengan tahun 2033 secara annual ditunjukkan dalam Tabel 2 dan gambaran pola peningkatan sebagaimana ditunjukkan dalam Gambar 4 dan Gambar 5.

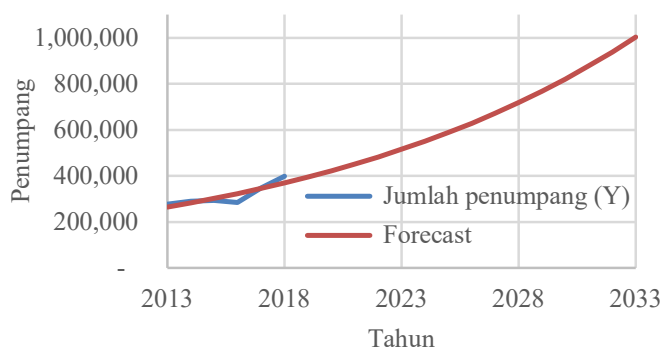

Gambar 4. Forecast arrival sampai 2033 


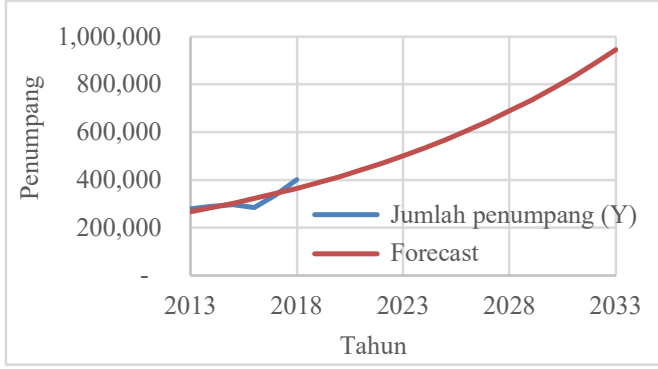

Gambar 5. Forecast departure sampai 2033

Tabel 2. Proyeksi arus penumpang sampai dengan tahun 2033

\begin{tabular}{|c|c|c|}
\hline Tahun & Forecast arrival & Forecast depatures \\
\hline 2019 & 394.658 & 389.305 \\
2020 & 421.851 & 414.792 \\
2021 & 450.918 & 441.948 \\
2022 & 481.987 & 470.882 \\
2023 & 515.197 & 501.710 \\
\hline 2024 & 550.695 & 534.557 \\
2025 & 588.639 & 569.554 \\
2026 & 629.197 & 606.842 \\
2027 & 672.550 & 646.571 \\
2028 & 718.890 & 688.901 \\
\hline 2029 & 768.424 & 734.003 \\
2030 & 821.370 & 782.057 \\
2031 & 877.964 & 833.258 \\
2032 & 938.457 & 887.810 \\
2033 & 1.003 .119 & 945.934 \\
\hline
\end{tabular}

Tabel 3. Proyeksi arus kapal sampai dengan tahun 2033

\begin{tabular}{|l|c|c|c|}
\hline Tahun & $\begin{array}{c}\text { Data Kunjungan } \\
\text { Kapal }\end{array}$ & Tahun & $\begin{array}{c}\text { Data Kunjungan } \\
\text { Kapal }\end{array}$ \\
\hline 2014 & 1.976 & 2024 & 2.723 \\
\hline 2015 & 2.041 & 2025 & 2.812 \\
\hline 2016 & 2.107 & 2026 & 2.903 \\
\hline 2017 & 2.176 & 2027 & 2.998 \\
\hline 2018 & 2.247 & 2028 & 3.095 \\
\hline 2019 & 2.320 & 2029 & 3.196 \\
\hline 2020 & 2.395 & 2030 & 3.300 \\
\hline 2021 & 2.473 & 2031 & 3.408 \\
\hline 2022 & 2.554 & 2032 & 3.519 \\
\hline 2023 & 2.637 & 2033 & 3.633 \\
\hline
\end{tabular}

\section{Kebutuhan Fasilitas Pelabuhan}

Kebutuhan fasilitas pelabuhan per tiap lima tahunan diproyeksikan sebagai berikut.

1. Dermaga

$$
L \rho(1(37,98)+(1+1) \times 10 \% \times 37,98)
$$$$
=45,57 \mathrm{~m}
$$

2. Terminal Penumpang

Kebutuhan Ruang Tunggu 2023

$=1,2 \mathrm{~m} /$ org $\times 2 \times 1,2 \times 286$ org/trip x 1,2

$=988 \mathrm{~m}^{2}$

Kebutuhan Ruang Tunggu 2028

$=1,2 \mathrm{~m} /$ org $\times 2 \times 1,2 \times 286$ org $/$ trip $\times 1,2$

$=988 \mathrm{~m}^{2}$

Kebutuhan Ruang Tunggu 2033

$=1,2 \mathrm{~m} /$ org $\times 2 \times 1,2 \times 286$ org $/$ trip $\times 1,2$

$=1483 \mathrm{~m}$

3. Areal Parkir

Kebutuhan Luasan Parkir 2023

$=13.899 \mathrm{~m}^{2}$

Kebutuhan Luasan Parkir 2028

$=13.899 \mathrm{~m}^{2}$

Kebutuhan Luasan Parkir 2033

$=20.848 \mathrm{~m}^{2}$

\section{Uji Validitas dan Reabilitas}

Berdasarkan perhitungan uji validitas dengan nilai $r$ tabel 0,195 (sig $5 \%$ ), dimana rata-rata $\mathrm{r}$ hitung $=0,97>0,195$, maka setiap atribut pada kuisioner dinyatakan VALID

Sedang pada uji reliabilitas untuk tingkat kinerja pelayanan dan tingkat kepentingan didapatkan nilai ri $=0,99>$ syarat 0,129 sehingga kuisioner tersebut dinyatakan reliabel.

\section{Kajian Sevice Quality dalam IPA}

Responden berasal dari penumpang dengan 2 jenis tiket yang berbeda, yakni 50 responden merupakan pemegang tiket reguler pengguna ruang tunggu reguler, sedangkan 50 responden lainnya merupakan penumpang dengan tiket VIP yang menggunakan Ruang tunggu Emerald Lounge. Namun dalam perhitungannya kedua hasil responden digabung, sehingga mendapatkan nilai ratarata yang cukup baik. Hasil bobot dan kinerja dapat dilihat pada Tabel 4, dan nilai rata-rata tingkat kualitas pelayanan serta tingkat kepentingan dapat dilihat pada Tabel 5. 
Tabel 4. Bobot dan kinerja pelayanan, kepuasan dan tingkat kepentingan responden

\begin{tabular}{|c|c|c|c|c|}
\hline \multicolumn{2}{|r|}{ Uraian Pernyataan } & \\
\hline A & Tangible & $\mathrm{Xi}$ & $\mathrm{Yi}$ & Tki $(\%)$ \\
\hline 1 & Kondisi terminal penumpang $\quad$ p.... & 366 & 456 & 80,26 \\
\hline 2 & Kelengkapan peralatan serta fasilitas pelayanan untuk penumpang & 369 & 455 & 81,10 \\
\hline 3 & Keadaan ruangan yang bersih serta nyaman & 372 & 456 & 81,58 \\
\hline 4 & Kelengkapan pakaian seragam petugas \sarana dan prasarana yang memadai & 375 & 455 & 82,42 \\
\hline $\mathrm{B}$ & Reability & & & \\
\hline 1 & Kecepatan pelayanan petugas dalam melayani penumpang & 384 & 453 & 84,77 \\
\hline 2 & Ketepatan waktu jadwal keberangkatan dan kedatangan kapal sesuai informasi petugas & 395 & 454 & 87,00 \\
\hline 3 & Kesesuaian pelayanan yang diberikan dengan kebutuhan penumpang & 388 & 453 & 85,65 \\
\hline 4 & Kesigapan petugas dalam menanggapi keluhan penumpang & 392 & 449 & 87,31 \\
\hline $\mathrm{C}$ & Responsiveness & & & \\
\hline 1 & Kesediaan petugas memberikan pelayanan dengan cepat kepada penumpang & 392 & 453 & 86,53 \\
\hline 2 & Kesiapasediaan petugas dalam menjawab pertanyaan dari penumpang & 393 & 453 & 86,75 \\
\hline 3 & Kerelaan petugas memberikan waktu dalam melayani penumpang & 389 & 452 & 86,06 \\
\hline 4 & Kespekaan petugas dalam menerima kritik dan saran dari penumpang & 391 & 453 & 86,31 \\
\hline $\mathrm{D}$ & Assurance & & & \\
\hline 1 & Kerahasiaan data pelanggan & 392 & 454 & 86,34 \\
\hline 2 & Kemampuan petugas dalam menjaga kepercayaan penumpang & 393 & 453 & 86,75 \\
\hline 3 & Jaminan keamanan dari pihak pelabuhan & 396 & 454 & 87,22 \\
\hline 4 & $\begin{array}{l}\text { Kemampuan petugas dalam memberikan perlindungan apabila terdapat resiko yang } \\
\text { terjadi kepada penumpang }\end{array}$ & 394 & 454 & 86,78 \\
\hline E & Emphaty & & & \\
\hline 1 & Kemudahan penumpang untuk menyampaikan keluhan & 394 & 452 & 87,17 \\
\hline 2 & Pemahaman petugas atas kebutuhan penumpang & 392 & 451 & 86,92 \\
\hline 3 & Keramahan petugas dalam memberikan pelayananan & 394 & 450 & 87,56 \\
\hline 4 & Pelayanan yang diberikan merata kepada semua penumpang tanpa memandang status & 376 & 451 & 83,37 \\
\hline & TOTAL & 7737 & 9061 & $85,39 \%$ \\
\hline
\end{tabular}

Tabel 5. Nilai rata - rata tingkat kinerja dan kepentingan kualitas pelayanan

\begin{tabular}{|c|c|c|c|c|c|}
\hline \multicolumn{2}{|r|}{ Uraian Pernyataan } & \\
\hline A & Tangible & $\mathrm{Xi}$ & $\mathrm{Yi}$ & $\dot{\mathrm{x}}$ & $\overline{\mathrm{y}}$ \\
\hline 1 & Kondisi terminal penumpang & 366 & 456 & 3,66 & 4,56 \\
\hline 2 & Kelengkapan peralatan serta fasilitas pelayanan untuk penumpang & 369 & 455 & 3,69 & 4,55 \\
\hline 3 & Keadaan ruangan yang bersih serta nyaman & 372 & 456 & 3,72 & 4,56 \\
\hline 4 & Kelengkapan pakaian seragam petugas \sarana dan prasarana yang memadai & 375 & 455 & 3,75 & 4,55 \\
\hline $\mathrm{B}$ & Reability & & & & \\
\hline 1 & Kecepatan pelayanan petugas dalam melayani penumpang & 384 & 453 & 3,84 & 4,53 \\
\hline 2 & $\begin{array}{l}\text { Ketepatan waktu jadwal keberangkatan dan kedatangan kapal sesuai } \\
\text { informasi petugas }\end{array}$ & 395 & 454 & 3,95 & 4,54 \\
\hline 3 & Kesesuaian pelayanan yang diberikan dengan kebutuhan penumpang & 388 & 453 & 3,88 & 4,53 \\
\hline 4 & Kesigapan petugas dalam menanggapi keluhan penumpang & 392 & 449 & 3,92 & 4,49 \\
\hline $\mathrm{C}$ & Responsiveness & & & & \\
\hline 1 & Kesediaan petugas memberikan pelayanan dengan cepat kepada penumpang & 392 & 453 & 3,92 & 4,53 \\
\hline 2 & Kesiapsediaan petugas dalam menjawab pertanyaan dari penumpang & 393 & 453 & 3,93 & 4,53 \\
\hline 3 & Kerelaan petugas memberikan waktu dalam melayani penumpang & 389 & 452 & 3,89 & 4,52 \\
\hline 4 & Kespekaan petugas dalam menerima kritik dan saran dari penumpang & 391 & 453 & 3,91 & 4,53 \\
\hline $\mathrm{D}$ & Assurance & & & & \\
\hline 1 & Kerahasiaan data pelanggan & 392 & 454 & 3,92 & 4,54 \\
\hline 2 & Kemampuan petugas dalam menjaga kepercayaan penumpang & 393 & 453 & 3,93 & 4,53 \\
\hline 3 & Jaminan keamanan dari pihak pelabuhan & 396 & 454 & 3,96 & 4,54 \\
\hline 4 & $\begin{array}{l}\text { Kemampuan petugas dalam memberikan perlindungan apabila terdapat } \\
\text { resiko yang terjadi kepada penumpang }\end{array}$ & 394 & 454 & 3,94 & 4,54 \\
\hline $\mathrm{E}$ & Emphaty & & & & \\
\hline 1 & Kemudahan penumpang untuk menyampaikan keluhan & 394 & 452 & 3,94 & 4,52 \\
\hline 2 & Pemahaman petugas atas kebutuhan penumpang & 392 & 451 & 3,92 & 4,51 \\
\hline 3 & Keramahan petugas dalam memberikan pelayananan & 394 & 450 & 3,94 & 4,5 \\
\hline 4 & $\begin{array}{l}\text { Pelayanan yang diberikan merata kepada semua penumpang tanpa } \\
\text { memandang status }\end{array}$ & 376 & 451 & 3,76 & 4,51 \\
\hline & $\begin{array}{ll} & \\
\end{array}$ & 7737 & 9061 & 77,3 & 90,6 \\
\hline & TOTAL RATA - RATA & & & 3,87 & 4,53 \\
\hline
\end{tabular}


Kegiatan pelayanan terminal penumpang Pelabuhan BBT secara cartesian tergambar dalam Gambar 6.

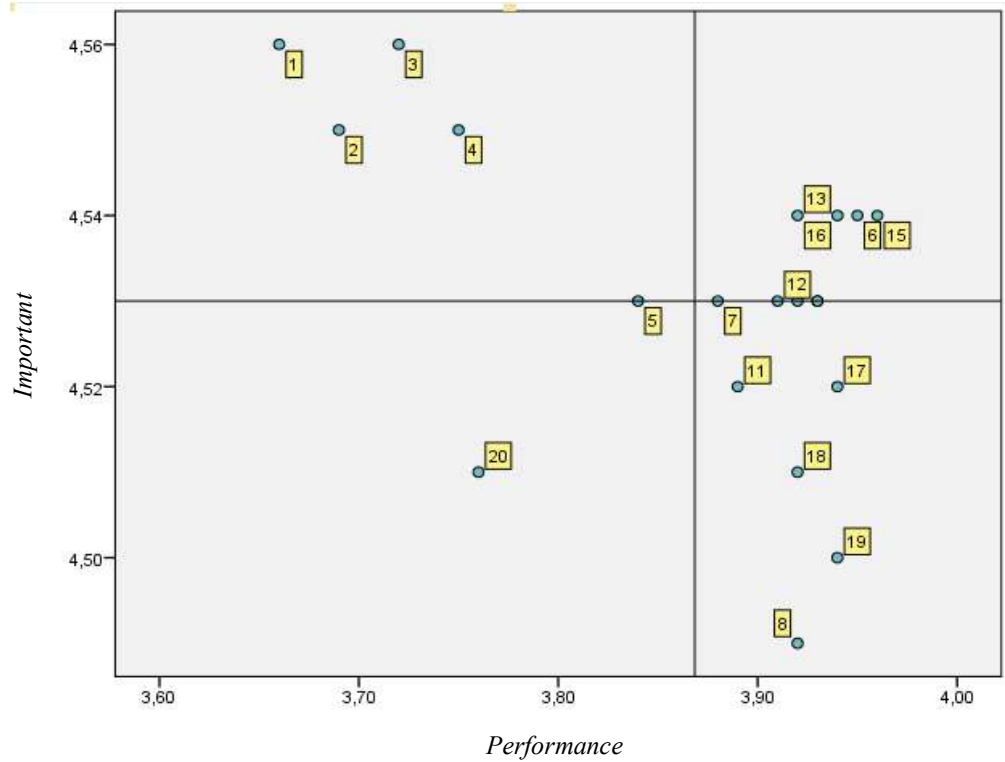

Gambar 6. Diagram kartesius kegiatan pelayanan terminal penumpang Pelabuhan BBT

Penjelasan dari faktor-faktor dalam diagram kartesius kegiatan pelayanan terminal penumpang Pelabuhan BBT adalah sebagai berikut.

\section{Kuadran A (prioritas utama)}

Faktor-faktor ini yang dinilai sangat penting oleh pelanggan sedangkan tingkat pelaksanaannya masih belum memuaskan pengguna jasa, antara lain:

1. kondisi terminal penumpang,

2. kelengkapan peralatan serta fasilitas pelayanan untuk penumpang,

3. keadaan ruangan yang bersih serta nyaman,

4. kelengkapan pakaian seragam petugas sarana dan prasarana yang memadai.

\section{Kuadran B (pertahankan prestasi)}

Faktor-faktor ini harus dipertahankan karena pada umumnya tingkat pelaksanaan-nya telah sesuai dengan kepentingan dan harapan pengguna jasa, antara lain:
1. ketepatan waktu jadwal keberangkatan dan kedatangan kapal sesuai informasi petugas,

2. kesesuaian pelayanan yang diberikan dengan kebutuhan penumpang,

3. kesediaan petugas memberikan pelayanan dengan cepat kepada penumpang,

4. kesiapsediaan petugas dalam menjawab pertanyaan dari penumpang,

5. kepekaan petugas dalam menerima kritik dan saran dari penumpang,

6. kerahasiaan data pelanggan,

7. kemampuan petugas dalam menjaga kepercayaan penumpang,

8. jaminan keamanan dari pihak pelabuhan,

9. kemampuan petugas dalam memberikan perlindungan apabila terdapat resiko yang terjadi kepada penumpang.

\section{Kuadran C (prioritas rendah)}

Faktor-faktor ini masih dianggap kurang penting bagi pengguna jasa sedangkan 
kualitasnya pelaksanaannya biasa saja antara lain:

1. kecepatan pelayanan petugas dalam melayani penumpang,

2. pelayanan yang diberikan merata kepada semua penumpang tanpa memandang status.

\section{Kuadran D (berlebihan)}

Faktor-faktor tersebut dinilai berlebihan dalam pelaksanaannya di karenakan pengguna jasa menganggap tidak terlalu penting terhadap adanya faktor tersebut, akan tetapi pelaksanaannya dilakukan dengan baik sekali, sehingga sangat memuaskan antara lain:

1. kesigapan petugas dalam menanggapi keluhan penumpang,

2. kerelaan petugas memberikan waktu dalam melayani penumpang,

3. kemudahan penumpang untuk menyampaikan keluhan,

4. pemahaman petugas atas kebutuhan penumpang,

5. keramahan petugas dalam memberikan pelayananan.
Tabel 6. Tingkat kepuasan responden secara keseluruhan

\begin{tabular}{|c|l|c|c|}
\hline No & \multicolumn{1}{|c|}{ Kulitas Pelayanan } & $\begin{array}{c}\text { Jumlah } \\
\text { (Orang) }\end{array}$ & $\begin{array}{c}\text { Persentase } \\
(\%)\end{array}$ \\
\hline 1 & Sangat Memuaskan & 29 & 29 \\
\hline 2 & Memuaskan & 39 & 39 \\
\hline 3 & Cukup memuaskan & 23 & 23 \\
\hline 4 & Kurang Memuaskan & 8 & 8 \\
\hline 5 & Tidak memuaskan & 1 & 1 \\
\hline \multicolumn{2}{|c|}{ Total } & 100 & 100 \\
\hline
\end{tabular}

\section{Kajian SWOT}

Variabel dan atribut SWOT untuk variable IFAS (Tabel 7) diperoleh dari hasil analisis $I P A$, sedangkan untuk variable $E F A S$ (Tabel 8) diperoleh melalui hasil wawancara terhadap 6 responden yakni 4 orang responden merupakan pengelola pelabuhan BBT dan 2 orang responden lainnya merupakan visitor yang dipilih secara acak. Bobot atribut didasarkan pada tingkat kepentingan dari hasil analisis, serta hasil wawancara dengan pihak pengelola Pelabuhan BBT.

Tabel 7. Matriks IFAS

\begin{tabular}{|c|c|c|c|c|c|}
\hline \multicolumn{6}{|c|}{ Atribut } \\
\hline $\mathrm{A}$ & Kekuatan & Jumlah & Bobot & Rating & Total \\
\hline 1 & $\begin{array}{l}\text { Ketepatan waktu jadwal keberangkatan dan kedatangan kapal sesuai } \\
\text { informasi petugas. }\end{array}$ & 30 & 0,14 & 5 & 0,72 \\
\hline 2 & Kesesuaian pelayanan yang diberikan dengan kebutuhan penumpang & 27 & 0,13 & 5 & 0,58 \\
\hline 3 & Kemampuan petugas dalam menjaga kepercayaan penumpang & 25 & 0,12 & 4 & 0,50 \\
\hline 4 & Jaminan keamanan dari pihak pelabuhan & 30 & 0,14 & 5 & 0,72 \\
\hline $\mathrm{B}$ & Kelemahan & & & & \\
\hline 1 & $\begin{array}{l}\text { Kecepatan pelayanan petugas dalam melayani penumpang belum } \\
\text { maksimal }\end{array}$ & 26 & 0,12 & 4 & 0,54 \\
\hline 2 & $\begin{array}{l}\text { Belum meberikan Pelayanan yang merata kepada semua penumpang } \\
\text { karena terdapat perbedaan yang cukup signifikan anatar penumpang } \\
\text { dengan elas reguler dan kelas VIP }\end{array}$ & 22 & 0,11 & 4 & 0,39 \\
\hline 3 & Kondisi terminal penumpang & 24 & 0,11 & 4 & 0,46 \\
\hline 4 & Kelengkapan fasilitas pelayanan untuk penumpang & 25 & 0,12 & 4 & 0,50 \\
\hline \multicolumn{2}{|r|}{ TOTAL } & 209 & 1,00 & 35 & 4,40 \\
\hline
\end{tabular}

Tabel 8. Matriks EFAS

\begin{tabular}{|c|l|c|c|c|c|}
\hline No & \multicolumn{1}{|c|}{ Atribut } & \multicolumn{1}{|c|}{ Total } \\
\hline C & Peluang & Jumlah & Bobot & Rating & \multicolumn{1}{|c|}{ Total } \\
\hline 1 & Kegiatan wisata (travelling) sedang menjadi trend & 23 & 0,13 & 4 & 0,48 \\
2 & $\begin{array}{l}\text { Akan dibangun 20 destinasi wisata baru pada kawasan Bintan } \\
\text { International Resort (Lagoi) 15 tahun kedepan }\end{array}$ & 26 & 0,14 & 4 \\
4 & $\begin{array}{l}\text { Kegiatan Olahraga berskala international yang merupakan agenda } \\
\text { rutin di Bintan Beach International Resort semakin populer } \\
\text { Dukungan Pemerintah pusat terhadap pengembangan kawasan } \\
\text { industri pariwisata di Bintan Beach International Resort }\end{array}$ & 27 & 0,15 & 5 & 0,66 \\
\end{tabular}


(lanjutan Tabel 8. Matriks EFAS)

\begin{tabular}{|c|c|c|c|c|c|}
\hline $\mathrm{D}$ & Ancaman & & & & \\
\hline 1 & $\begin{array}{l}\text { Adanya pelabuhan khusus (TUKS) dengan fungsi serupa di sekitar } \\
\text { Pelabuhan BBT }\end{array}$ & 21 & 0,11 & 4 & 0,40 \\
\hline 2 & $\begin{array}{l}\text { Kurangnya informasi mengenai kawasan Bintan International } \\
\text { Resort terutama pada wisatawan domestik }\end{array}$ & 18 & 0,10 & 3 & 0,29 \\
\hline 3 & $\begin{array}{l}\text { Pesaing utama bintan resort yakni pusat wisata di pulau Batam, } \\
\text { Malaysia dan Singapura terkadang memberikan penawaran bagus } \\
\text { untuk manrik minat wisatawan }\end{array}$ & 21 & 0,11 & 4 & 0,40 \\
\hline 4 & Kenaikan seaport taxes & 23 & 0,13 & 4 & 0,48 \\
\hline \multicolumn{2}{|r|}{ TOTAL } & 184 & 1,00 & 31 & 3,89 \\
\hline
\end{tabular}

Tabel 9. Matriks SWOT

\begin{tabular}{|c|c|c|}
\hline & $\begin{array}{l}\text { Kekuatan (Strengths) } \\
\text { 1. Ketepatan waktu jadwal keberangkatan } \\
\text { dan kedatangan kapal sesuai informasi } \\
\text { petugas. } \\
\text { 2. Kesesuaian pelayanan yang diberikan } \\
\text { dengan kebutuhan penumpang. } \\
\text { 3. Kemampuan petugas dalam menjaga } \\
\text { kepercayaan penumpang. } \\
\text { 4. Jaminan keamanan dari pihak } \\
\text { pelabuhan. }\end{array}$ & $\begin{array}{l}\text { Kelemahan (Weaknesses) } \\
\text { 1. Kecepatan pelayanan petugas dalam me- } \\
\text { layani penumpang. } \\
\text { 2. Belum memberikan pelayanan yang } \\
\text { merata kepada semua penumpang karena } \\
\text { terdapat perbedaan yang cukup signif- } \\
\text { ikan antara penumpang dengan kelas } \\
\text { regular dan kelas VIP. } \\
\text { 3. Kondisi terminal penumpang. } \\
\text { 4. Kelengkapan fasilitas pelayanan untuk } \\
\text { penumpang. }\end{array}$ \\
\hline $\begin{array}{l}\text { Peluang (Opportunities) } \\
\text { 1. Kegiatan wisata (travelling) } \\
\text { sedang menjadi trend. } \\
\text { 2. Akan dibangun } 20 \text { destinasi } \\
\text { wisata baru pada Kawasan } \\
\text { Bintan International Resort } \\
\text { (Lagoi) sampai dengan } 15 \text { ta- } \\
\text { hun kedepan. } \\
\text { 3. Kegiatan olahraga berskala } \\
\text { internasioanl yang merupa- } \\
\text { kan agenda rutin di Bintan } \\
\text { Beach International Resort } \\
\text { semakin popular. } \\
\text { Dukungan pemerintah ter- } \\
\text { hadap pengembangan Kawa- } \\
\text { san industry pariwisata di } \\
\text { Bintan Beach Internatioanl } \\
\text { Resort. }\end{array}$ & $\begin{array}{l}\text { Strategi S-O } \\
\text { 1. Menambah jumlah serta rute trip pela- } \\
\text { yanan (S1, O1, O2, O3, O4). } \\
\text { 2. Meningkatkan kuantitas fasilitas termi- } \\
\text { nal penumpang, menyediakan fasilitas } \\
\text { khusus seperti kios untuk menyewakan } \\
\text { peralatan olah raga maupun perlengka- } \\
\text { pan pendukung kegiatan wisata (S2, } \\
\text { O1, O2, O2). } \\
\text { 3. Meminimalisir delayed pada pelayanan } \\
\text { ferry, meminimalisir penumpang ke- } \\
\text { hilangan/kerusakan bagasi (luggage), } \\
\text { menambah personil pada bagian pela- } \\
\text { yanan agar kondisi terminal tetap kon- } \\
\text { dusif (tidak chaos) (S3, O1, O2, O3). } \\
\text { Melibatkan pemerintah dalam } \\
\text { mengawasi jalannya kegiatan di } \\
\text { pelabuhan, menambah personil untuk } \\
\text { menjaga keamanan, melengkapi fasili- } \\
\text { tas pendukung keamanan (S1, O1, O2, } \\
\text { O3, O4). }\end{array}$ & $\begin{array}{l}\text { Strategi W-O } \\
\text { 1. Perbaikan/rehabilitasi gedung terminal, } \\
\text { menciptakan suasanan gedung yang unik } \\
\text { serta menarik minat wisatawan (W3, O1, } \\
\text { O2, O3, O4). } \\
\text { 2. Mengurangi disparitas pelayanan dengan } \\
\text { peningkatan kualitas pelayanan pada } \\
\text { penumpang regular serta pengingkatan } \\
\text { kapasitas lounge pada penumpang VIP } \\
\text { (W2, O1, O2). } \\
\text { 3enambah counter pembelian tiket dan } \\
\text { check-in, menyediakan mesin portable } \\
\text { yang memudahkan penumpang untuk } \\
\text { melakukan swa-beli/swa-check in, atau } \\
\text { menyediakan fasilitas beli/check-in } \\
\text { secara online (W1, O1, O2, O3, O4). } \\
\text { Melengkapi fasilitas pendukung kegiatan } \\
\text { operasional pelabuhan yang menjadi } \\
\text { kebutuhan penumpang, melibatkan } \\
\text { pemerintah dalam memenuhi sandar } \\
\text { kebutuhan penumpang dalam kegiatan } \\
\text { operasional (W4, O1, O2, O3, O4). }\end{array}$ \\
\hline Ancaman (Threats) & & Strategi W-T \\
\hline $\begin{array}{l}\text { 1. Adanya pelabuhan khusus } \\
\text { (TUKS) dengan fungsi se- } \\
\text { rupa di sekitar Pelabuhan } \\
\text { BBT. } \\
\text { 2. Kurangnya informasi } \\
\text { mengenai Kawasan Bintan } \\
\text { Internatioanl Resort terutama } \\
\text { pada wisatawan domestik. } \\
\text { 3. Pesaing utama Bintan Inter- } \\
\text { national Resort yakni pusat } \\
\text { wisata di Pulau Batam, Mal- }\end{array}$ & $\begin{array}{l}\text { 1. Untuk tetap bersaing dengan kompeti- } \\
\text { tor, pengelola harus menyediakan } \\
\text { layanan one stop service dimana } \\
\text { penumpang dapat melakukan pen- } \\
\text { gecekan visa dan keimigrasian on } \\
\text { board bahkan Ketika belum berlabuh di } \\
\text { pelabuhan (S2, T2, T3). } \\
\text { 2. Mengikuti arah perkembangan di era } \\
\text { digital saat ini dengan menggunakan } \\
\text { media social sebagai sarana promosi } \\
\text { (S2, T2, T3). }\end{array}$ & $\begin{array}{l}\text { 1. Menambah personil untuk melayani } \\
\text { penumpang, atau menyediakan web agar } \\
\text { penumpang dapat melakukan pembelian } \\
\text { tiket/check-in secara online (W1, T1, } \\
\text { T3). } \\
\text { 2. Membuat iklan atau reklame di berbagai } \\
\text { media untuk memberikan voucher atau } \\
\text { potongan harga untuk tiket VIP sehingga } \\
\text { terjangkau oleh semua penumpang dan } \\
\text { bisa merasakan pelayanan terbaik dari } \\
\text { pelabuhan BBT (W2, T1, T2, T3). }\end{array}$ \\
\hline
\end{tabular}


(lanjutan Tabel 9. Matriks SWOT)

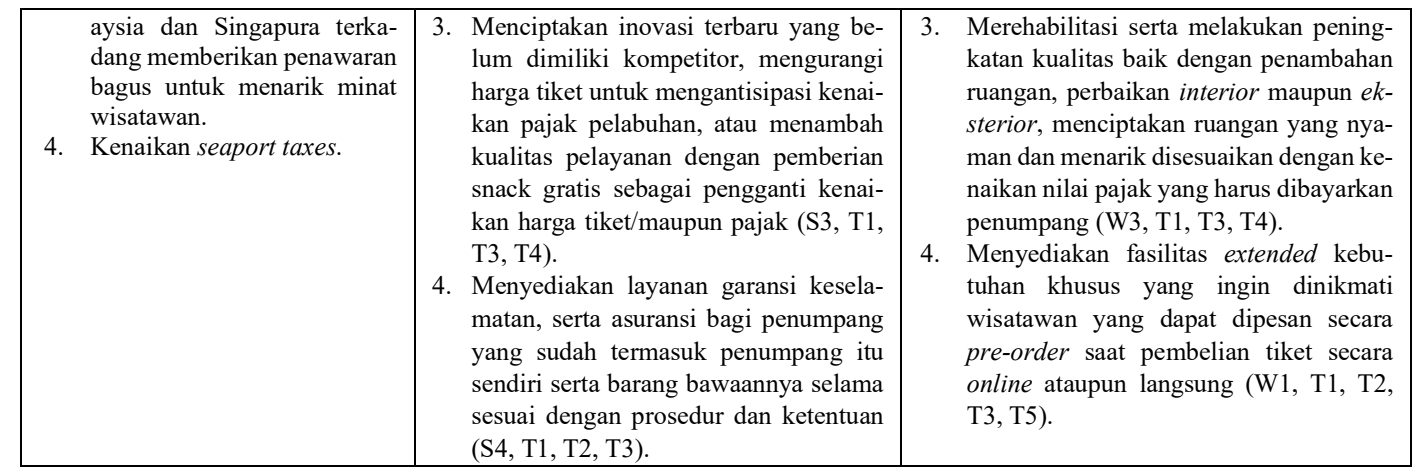

Secara lengkap matriks SWOT disajikan dalam Tabel 9, sedangkan matriks terkait grand strategy SWOT disajikan dalam Gambar 7.

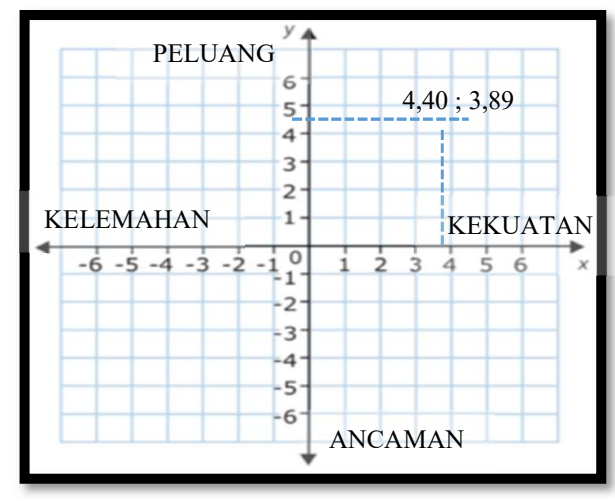

Gambar 7. Matriks grand strategy

\section{KESIMPULAN}

1. Fasilitas Ruang Tunggu membutuhkan perluasan sebesar $188 \mathrm{~m}^{2}$ sampai dengan tahun 2028 dan $613 \mathrm{~m}^{2}$ pada tahun 2033. Selain itu, perluasan sebesar $17.173 \mathrm{~m}^{2}$ juga dibutuhkan untuk lahan parkir menginap dan $957 \mathrm{~m}^{2}$ untuk lahan parkir pengantar dan penjemput;

2. (BOR) pada Dermaga Pelabuhan BBT masih dalam kategori baik dilihat dari nilai BOR Pelabuhan BBT sebesar $24,11 \%$ dari syarat UNCTAD untuk dermaga 2 tambatan yakni sebesar $50 \%$;

3. Pada dasarnya pelayanan pelabuhan BBT sudah cukup baik, namun kondisi gedung yang belum pernah direnovasi sejak tahun 1994 mengurangi nilai tampilan visual gedung terminal.

4. Rencana perbaikan serta peningkatan fasilitas pelabuhan perlu dikembangkan secara bertahap meliputi rencana jangka pendek, menengah dan jangka panjang.

5. Melalui Kajian SWOT dihasilkan titik pada kuadran II yakni mendukung strategi agresif, dimana, strategi yang dirumuskan yang akan membantu pengelola pelabuhan BBT untuk mengatasi permasalahan eksternal yang akan dihadapi dimasa yang akan datang.

\section{DAFTAR PUSTAKA}

Kementerian Perhubungan Republik Indonesia. (2004) "Keputusan Menteri Perhubungan Nomor KP. 52 Tahun 2004 Tentang Penyelenggaraan Pelabuhan Penyebrangan". Kementerian Perhubungan Republik Indonesia. Jakarta

Andiani, D. (2011). "Terminal Feri Domestik Arsitektur Simbolis Medan”. Tugas Akhir. Program Studi Arsitektur Universitas Sumatera Utara. Medan

Arikunto, S. (2013). "Prosedur penelitian Suatu Pendekatan Praktik”. Jakarta : PT. Rineka Cipta.

Debra, T. L. (2019). “Perencanaan Pengembangan Pelabuhan Manado Sebagai 
Pelabuhan Pariwisata". Teknik Sipil Universitas Sam Ratulangi. Manado

Putra, A. (2016). "Pengembangan Infrastruktur Pelabuhan Dalam Mendukung Pembangunan Berkelanjutan". Teknik Sipil Universitas Haluoleo. Kendari

Martilla, J., James, J. (1977). "ImportancePerformance Analysis". The Journal of Marketing. 41(1):77- 79.

Rangkuti, F. (2004). “Analisis SWOT Teknik Membedah Kasus Bisnis". Jakarta: PT. Gramedia Pustaka Utama.

Robert, E. (2018). "Analisis Kinerja Pelayanan Pelabuhan Penyebrangan Bolok Kupang','. Program Studi Magister Sistem Teknik Transportasi. Universitas Gadjah Mada. Yogyakarta

Ruslin, (2018). “Analisis Kinerja Pelayanan Operasional Terminal Petikemas
Pelabuhan Soekarno Hatta”. Program Studi Magister Sistem Teknik Transportasi. Universitas Gadjah Mada. Yogyakarta

Tjiptono, Fandy dan Chandra, G. (2007). "Service, Quality \& Satisfaction". Yogyakarta: Penerbit Andi.

Triatmodjo, B. (2010). "Perencanaan Pelabuhan". Yogyakarta: Beta Offset.

Wibisono, Y. (2015). "Metode Statistik". Yogyakarta: Gadjah Mada University Press.

Widyanto, Y. (2019). "Evaluasi Fasilitas Eksisting Pelabuhan dan Rencana Pengembangan Pelabuhan Sunda Kelapa”. Program Studi Magister Sistem Teknik Transportasi. Universitas Gadjah Mada. Yogyakarta 